\title{
Ocular lubricants: what is the best choice?
}

\author{
Lubrificantes oculares - qual a melhor escolha?
}

\author{
Daniela Macedo Lins de Araújo ${ }^{I}$ Paula Diniz Galera ${ }^{{ }^{*}}$
}

\section{- REVIEW -}

\section{ABSTRACT}

Ocular lubricants are used to supplement one or more layers of the lacrimal film. They are often prescribed to treat keratoconjunctivitis sicca (KCS) and other diseases of ocular surface in humans. These lubricants may also protect the ocular surface and promote epithelial regeneration. The active component of ocular lubricants is the lubricating agent. The key properties of different lubricating agents are the electrolyte composition, osmolarity, and addition of preservatives. Although lacrimomimetics are not typically used to treat $K C S$ in dogs, they can be used as an adjunctive therapy. Knowledge of the properties of lacrimomimetics will help in making the appropriate therapeutic choice.

Key words: Lacrimomimetics, ocular lubricants, artificial tears, keratoconjunctivitis sicca.

\section{RESUMO}

Lubrificantes oculares são usados como suplementos de uma ou mais camadas do filme lacrimal. São frequentemente prescritos para o tratamento da ceratoconjuntivite seca (CCS) no homem e em outras afecções da superfície ocular. Seu uso também pode gerar proteção da superfície ocular e promover regeneração epitelial. Os principais componentes de sua formulação são os agentes lubrificantes e as principais propriedades são a composição eletrolítica, a osmolaridade e a presença de conservantes. Embora lacrimomiméticos não sejam o tratamento da CCS em cães, eles podem ser utilizados como terapia adjuvante. O conhecimento de suas propriedades auxiliará na melhor opção terapêutica.

Palavras-chave: lacrimomiméticos, lubrificantes oculares, lágrimas artificiais, ceratoconjuntivite seca.

\section{INTRODUCTION}

Lacrimomimetics, or artificial tears, are synthetic ocular lubricants that supplement one or more components of the lacrimal film by increasing the tear volume and stability and by protecting the ocular surface against desiccation (DEWS, 2007). They are mostly prescribed as an adjunctive therapy for qualitative and quantitative film abnormalities, such as keratoconjunctivitis sicca (KCS) (GRAHN \& STOREY, 2004; DEWS, 2007; RIBEIRO et al., 2008). Canine keratoconjunctivitis sicca is a disease characterized by deficient tear production. Deficient tear production is often immune-mediated and is typically treated with immunomodulator agents (for example cyclosporine A, pimecrolimus, and tacrolimus), which stimulate tear production (WILLIAMS, 2008; RIBEIRO et al., 2008). Lacrimomimetics are only prescribed as an adjunct until normal tear production is restored (GRAHN \& STOREY, 2004). Other applications of these lubricants include adjuvant therapy of exposure keratitis, canine superficial punctate keratitis, as a lubricant during surgery and as a diluent for ophthalmic solutions (MAGGS et al., 2008). In feline patients, lacrimomimetics can be used to hydrate the ocular surface in cases of feline herpesvirus type 1 corneal alterations (MAGGS, 2005; MAGGS et al., 2008). It is also used to improve tear quality in cases

IFaculdade de Agronomia e Medicina Veterinária (FAV), Universidade de Brasília (UnB), Campus Darcy Ribeiro, Asa Norte, ICC Sul, 70910-970, Brasilia, DF, Brasil. E-mail: dra.paulagalera@gmail.com. *Corresponding author. 
of indolent ulcers and for keratitis in cases of corneal sequestration, where surgical procedure should be performed (MOORE, 2005; MAGGS et al., 2008).

While the composition of artificial tears must be similar to that of natural tears in order to simulate its organic characteristics, the full complexity of the lacrimal film cannot be reproduced yet (DEWS, 2007, DOGRU et al., 2013). Consequently, the formulations of ocular lubricants are constantly being revised and updated (DOGRU et al., 2013). Given the variety of available products, the aim of this review was to present the main formulations of lacrimomimetics and their effect on the ocular surface, and thus guide clinicians on the best choice for each individual patient.

\section{DEVELOPMENT}

An ideal lacrimomimetic must provide an environment compatible with the maintenance of the ocular physiology and must support epithelial healing (UBELS et al., 1995). Among the available options, special attention should be given to the lubricating agents and to some of their key properties: electrolyte composition, osmolarity, and presence of preservatives (GRAHN \& STOREY, 2004).

\section{Lubricant agents}

Fully functioning lubrication by the lacrimal film is necessary for the maintenance of ocular health and for proper interaction between the structures of the ocular surface (SCHMIDT et al., 2013). Disorders of the ocular surface increase the friction of the eyelids over the cornea and conjunctiva, which can be minimized with the addition of lubricants or viscosity agents (DEWS, 2007; SCHMIDT et al., 2013). Furthermore, the formulations of lacrimomimetics must accommodate the necessity of intermittent instillation, while aiming to mimic the continual production of natural tears (DOGRU et al., 2013). Thus, viscosity agents are included in the formulation in order to increase the contact time of the drop with the ocular surface and extend comfort duration (DEWS, 2007).

The disadvantages of such agents are the blurring of vision and the accumulation in the eyelashes, which is more evident in thicker solutions (CALONGE, 2001; DEWS, 2007). For veterinary patients, because quality of life can be prioritized over visual acuity, the blurring of vision is not a main concern (MOORE, 1999). The most commonly used lubricating agents used are cellulose derivatives, sodium hyaluronate, synthetic polymers, hydroxypropyl-guar, and glycerin (GRAHN \& STOREY, 2004; SPRINGS, 2010; DOGRU et al., 2013) (Table 1).

Cellulose derivatives are polysaccharides with good ocular surface retention time and lubricant action; they are non-irritants that can be used in association with other ophthalmic formulations. Among them, the most common are carboxymethylcellulose (CMC) and hypromellose (HPMC) (CALONGE, 2001; DOGRU et al., 2013).

Carboxymethylcellulose is the most commonly used agent in commercial formulations, as it has desirable mucoadhesive and viscoelastic properties and a high retention time on the ocular surface (GARRET et al., 2007; DEWS, 2007; COLLIGRIS et al., 2014). It reduces the signs and symptoms of KCS in humans (SIMMONS \& VEHIGE, 2007). Moreover, its ability to stimulate cellular migration has been established in vitro and in animal models (rabbits), where CMC binds to the corneal epithelial cells and supports the healing of epithelial defects (GARRETT et al., 2007; GARRETT et al., 2008).

$\mathrm{CMC}$ is usually used in concentrations of $0.25 \%, 0.5 \%$, and $1 \%$ and with different molecular weights ranging from an equivalent of less than 5 to more than 1000 centipoise (DEWS, 2007; SIMMONS \& VEHIGE, 2007). Concentrations higher than $1 \%$ can cause blurring of vision and secretion of sticky material in humans, but provide a higher retention time on the ocular surface, and hence require fewer daily instillations (SIMMONS\& VEHIGE, 2007). Hypromellose is another viscoelastic polysaccharide with good retention properties. While it is commonly used, it has the disadvantage of encrusting the eyelids, which may mimic blepharitis in humans (CALONGE, 2001).

Sodium Hyaluronate (SH) is a glycosaminoglycan, present in natural tears, with excellent viscoelastic, lubricating and water retention properties (MOORE, 1999). There are many reports of its efficacy and safety (COLLIGRISet al., 2014). Its retention time on the ocular surface is high and it promotes epithelial cell migration, thereby supporting epithelial healing (GOMES et al., 2004; DEWS, 2007, DOGRU et al., 2013). There is also evidence that $\mathrm{SH}$ has a direct role in ocular inflammation and in cellular adhesion and migration (GOMES et al., 2004; DOGRU et al., 2013).

The combination of $\mathrm{CMC}$ and $\mathrm{SH}$ has high viscosity under low friction conditions (between blinking), thus stabilizing the tear film, but low viscosity under high friction conditions (during the blinking), thus it causes less adverse effects such as 
Table 1 - Main commercial ocular lubricants found currently on the Brazilian market. CMC: Carboxymethylcellulose; HPMC: Hypromellose; PEG 400/PE+HPG: Polyethylene glycol 400/propylene glycol thydroxypropyl-guar; SH: Sodium hyaluronate; BAK: Benzalkonium chloride.

\begin{tabular}{|c|c|c|c|}
\hline Product & Main csmponent & Preservative & Laboratory \\
\hline Adaptis & CMC $0.5 \%$ or $1 \%$ & Sodium perborate & Legrand \\
\hline Ecofilm & CMC $0.5 \%$ & Sodium perborate & Latinofarma \\
\hline Fresh Tears & CMC $0.5 \%$ & Prurite & Allergan \\
\hline Fresh Tears Liquigel & CMC $1 \%$ & Prurite & Allergan \\
\hline Lacrifilm & CMC $0.5 \%$ & Sodium perborate & Genom \\
\hline Optive* & CMC, glycerin & None (single-use vials) & Allergan \\
\hline Optive UD* & CMC, glycerin & None (single-use vials) & Allergan \\
\hline Plenigell* & CMC, glycerol & & Latinofarma \\
\hline Refresh Optive Advanced* & $\begin{array}{l}\text { CMC } 0.5 \% \text {, glycerol } 1 \% \text {, polysorbate } 800.5 \% \text {, castor } \\
\text { oil } 0.25 \%\end{array}$ & Prurite & Allergan \\
\hline Artelac & НРМС $0.32 \%$ & Cetrimide & Bausch\&Lomb \\
\hline Filmcel & HPMC $0.5 \%$, polysorbate 80 , Povidone & Parabens & Allergan \\
\hline Lacribell & HPMC $0.3 \%$, dextran $700.1 \%$ & BAK & Latinofarma \\
\hline Lacrima Plus & HPMC $0.3 \%$, dextran $700.1 \%$ & Polyquad & Alcon \\
\hline Trisorb & HPMC $0.3 \%$, dextran $700.1 \%$, glycerol $0.2 \%$ & Polyquad & Alcon \\
\hline Genteal Gel & HPMC $0.3 \%$, carbomer 980 (polyacrylic acid) $0.22 \%$ & GenAqua(Sodium perborate) & Alcon \\
\hline Liposic & Carbomer $9800.2 \%$ & Cetrimide & Bausch\&Lomb \\
\hline Adaptis Gel & Carbomer $9800.2 \%$ & Cetrimide & Legrand \\
\hline Refresh Gel & Carbomer $9800.3 \%$ & BAK & Allergan \\
\hline Vidsic Gel & Carbomer $9800.2 \%$ & Cetrimide & Bausch\&Lomb \\
\hline Mirugell & $\mathrm{PEG} 400 / \mathrm{PE}+\mathrm{HPG}$ & & Latinofarma \\
\hline Oftane & $\mathrm{PEG} 400 / \mathrm{PE}+\mathrm{HPG}$ & Polyquad & Alcon \\
\hline Systane UL & PEG400/PE+HPG & Polyquad & Alcon \\
\hline Hyabak & SH $0.15 \%$ & None (multi-use vial) & Genom \\
\hline Hylo-Comod & $\mathrm{SH} 0.1 \%$ & None (multi-use vial) & Pfizer \\
\hline Hylo-Gel & $\mathrm{SH} 0.2 \%$ & None (multi-use vial) & Pfizer \\
\hline Lacril & Polyvinyl alcohol $14 \mathrm{mg} / \mathrm{mL}$ & Chlorobutanol & Allergan \\
\hline Hypotears Plus & Povidone $5 \%$ & BAK & Novartis \\
\hline Endura & Glycerin, polysorbate 80 , carbomer, castor oil & Prurite & Allergan \\
\hline Endurasemconservantes & Glycerin, polysorbate 80 , Carbomer, castor oil & Free(single-use vials) & Allergan \\
\hline
\end{tabular}

discomfort in humans (SIMMONS et al., 2015b). SIMMONS et al. (2015b) tested this association by comparing three formulations: $\mathrm{CMC} 0.5 \%$ and $\mathrm{SH}$ $0.1 \%$, CMC $0.5 \%$ and $\mathrm{SH} 0.15 \%$, and CMC $0.5 \%$ (Refresh Tears $\left.^{\circledR}\right)$. The analysis showed that the combination of CMC and SH was well tolerated and led to better treatment outcomes, causing less adverse effects when compared to one polymer alone.

Synthetic polymeric lubricants that are commonly used are carbomer (polyacrylic acid) and povidone (polyvinylpyrrolidone). Carbomer is a polymer with a high viscosity and a good retention time, but it causes intense blurring (CALONGE, 2001). Povidones are linear polymers with mucinomimetic properties and have a good retention time (CALONGE, 2001). They are often added to cellulose-based solutions to supplement both the aqueous and mucin layers of the tear film or to polyvinylic alcohol solutions to increase wetting of the ocular surface (CALONGE, 2001; GRAHN \& STOREY, 2004).

Hydroxypropyl-guar (HPG) is used in combination with polyethylene glycol 400 (PEG) and propylene glycol (PG) as a gelling agent that adapts to the abnormalities of the lacrimal film and alterations on the ocular surface (CHRISTENSEN, 2008).

An ophthalmic formulation of HPG includes sorbitol and borate. The formulation is stored at $\mathrm{pH} 7$, at which sorbitol binds to borate. This promotes a low solution viscosity, which facilitates the instillation of the eye drops and decreases the immediate adverse effects. Once instilled in the eye, where the $\mathrm{pH}$ is around 7.5, this link is dissociated, and HPG binds to borate and forms a gel with bio adhesive 
properties, increasing the duration of exposure to the active ingredients (UBELS et al., 2004; DAVITT et al., 2010; SPRINGS, 2010). HPG molecules bind to the hydrophobic regions, i.e., areas where the glycocalyx integrity is compromised, and promoted local healing and lubrication (UBELS et al., 2004).

HPG solutions are an effective treatment for $\mathrm{KCS}$ as they increase the tear break up time (TBUT) (OUSLER et al., 2007). A commercial solution of HPG (Systane Ultra ${ }^{\circledR}$ ) has been shown to provide protection against desiccation in vivo (rabbit models) and in vitro, and provided a favorable environment for the regeneration of epithelial cells (UBELS et al., 2004). Comparisons between PEG/PG and HPG (Systane $^{\circledR}$ Gel Drops) with solutions of CMC $0.5 \%$ with glycerin and compatible solutes $\left(\right.$ Optive $\left.{ }^{\circledR}\right)$, CMC 1\% (Refresh LiquiGel $^{\circledR}$ ), and glycerin 1\% and polysorbate $80 \quad 1 \%$ (Refresh Endura $^{\circledR}$ ) have also demonstrated its superior efficacy (OUSLER et al., 2007; COHEN et al., 2014). However, some studies reported that there is no difference between the formulations Systane ${ }^{\circledR}$, Optive ${ }^{\circledR}$ and Refresh LiquiGel $^{\circledR}$ regarding the reduction of symptoms, consumer satisfaction, and safety of the product (DAVITT et al., 2010; COHEN et al., 2014).

Lipid ointments are an alternative to viscosity polymers. They are used to lubricate the ocular surface and supplement the lipid layer of the tear (MOORE, 1999; CALONGE, 2001; DEWS, 2007; HOPKINS, 2007; NICHOLS et al., 2011). Consequently, they increase the lacrimal stability and overcome the limitations of retention time that are seen in the aqueous agents (AMRANE et al., 2014). For humans, lipid ointments are indicated in cases of severe evaporative KCS and meibomian gland dysfunction (NICHOLS et al., 2011; ZHANG et al., 2014).

The most commonly used lubricating agents are petrolatum and mineral oil (MOORE, 1999; GRAHN\&STOREY, 2004). In some cases, lanolin is also used, but it can cause irritation and it retards regeneration of the corneal epithelium (DEWS, 2007). Because bacterial growth is limited in lipid ointments, most do not require the use of preservatives (DEWS, 2007).

Some recent reports have shown the beneficial properties of castor oil on the reestablishment of the tear lipid layer, and in the treatment of meibomian gland dysfunctions (KHANAL et al., 2007; SIMMONS et al., 2015a). The main component of the castor oil-based formulation is ricinoleic acid, an omega-9 unsaturated fatty acid that immediately spreads over the aqueous layer (SIMMONS et al., 2015a).
New strategies have been developed in recent years to reduce the adverse effects. VICARIODE-LA-TORRE et al. (2014) developed liposomes that contain phosphatidylcholine, cholesterol, vitamin E, and $\mathrm{SH}$ to replace the aqueous-mucin layer and increase the retention time. The $\mathrm{pH}$, osmolarity, viscosity, and surface tension of this solution are suitable for ophthalmic use and exhibited good tolerability in vitro and in vivo. Liposome products are already available in some countries (KHANAL et al., 2007).

Recently, cationic emulsions have also been introduced in the formulation of ocular lubricants. Cationic emulsions contain positively charged lipid droplets that are attracted to the negatively charged ocular surface through electrostatic interactions, thus increasing retention time (DU TOIT et al., 2011; AMRANE et al., 2014). The nano scale size of the droplets also amplifies their bioavailability (DU TOIT et al., 2011). AMRANE et al. (2014) developed cationic emulsions containing mineral oil and cetalkonium chloride. In a clinical trial, this formulation was compared to a polyvinyl acid and povidone lubricant $\left(\operatorname{Refresh}^{\circledR}\right)$. Both solutions increased the scores on the Schirmer test, decreased the fluorescein stain, and were considered comfortable and stable. However, the cationic emulsion had superior tear break up time and lissamine green stain results, indicating better integrity of the lacrimal film and protection of the ocular surface. Number of adverse effects was low in both groups. OUSLER et al. (2015) also showed its efficacy in reducing the signs and symptoms of dry eye and promoting tear stability. However, ointment use should be avoided in eyes with impending corneal perforations or deep or flap-like corneal lacerations before or during intraocular surgery (REGNIER, 2013).

\section{Properties of the Lacrimomimetics}

Electrolytes The addition of electrolytes, mainly bicarbonate and potassium, to artificial tears can be beneficial for the ocular surface. The correct electrolyte composition is essential to the maintenance of the goblet cell density and the corneal glycogen levels (GILBARD et al., 1989; DEWS, 2007). There is also evidence that the presence of calcium improves ocular surface symptoms as it is required for intercellular adhesion (TSUBOTA et al., 1999).

Lacrimomimetics usually have a neutral to mildly alkaline $\mathrm{pH}$ (HOPKINS, 2007). Solutions with a higher $\mathrm{pH}$ seem to increase ocular comfort (DOGRU et al., 2013). Sodium bicarbonate is frequently added to ophthalmic solutions as a buffer and provided a mildly alkaline $\mathrm{pH}$ (DOGRU et al., 2013). Besides 
its activity as a physiological buffer solution, the bicarbonate molecules also play a role in regenerating the epithelial barrier and maintaining the corneal ultra structure (UBELS et al., 1995; DOGRU et al., 2013). Other buffers include proteins, phosphate, acetate, and borate (DOGRU et al., 2013).

Osmolarity of the pre-corneal tear film is around $337 \mathrm{mOsmL}^{-1}$ in dogs, $238.5 \mathrm{mOsmL}^{-1}$ in cats, and $302 \mathrm{mOsmL}^{-1}$ in humans (TOMLINSON et al., 2006; DAVIS \& TOWNSEND, 2011; SEBBAG et al., 2014). However, large variations are reported in domestic animals. In cases of dry eye in humans, it has been well established that the osmotic pattern is altered due to the high evaporation rate and the reduced aqueous flow, which results in hyperosmolarity, above $316 \mathrm{mOsmL}^{-1}$ (DEWS, 2007; BAUDOUIN et al., 2013). Increased osmotic stress leads to oxidative damage and the activation of inflammatory cascades, which culminates in the death of goblet cells (MOORE et al., 2011; BAUDOUIN et al., 2013). Loss of goblet cells leads to alterations of the mucin layer, and hence further instability of the lacrimal film. This creates a vicious cycle that is central to the pathophysiology of the disease (MOORE et al., 2011; BAUDOUIN et al., 2013).

Thus, although many artificial tear formulations are isotonic, some have low osmolarity, with the aim of diluting the diseased tear film back to normal osmolarity (HOPKINS, 2007). While some studies have indicated that hypotonic solutions are superior regarding the improvement of symptoms and patient compliance, others failed to find significant differences between isotonic and hypotonic solutions (PAPA et al., 2001; ARAGONA et al., 2002; TROIANO \& MONACO, 2008). The main disadvantage of these drops is the limited ocular action (BAUDOUIN et al., 2013).

The addition of osmoprotectants has been reported to neutralize the damage caused by hyperosmolarity in patients with KCS (BAUDOUIN et al., 2013). The proposed mechanisms of action are antioxidant action, stabilization of protein surfaces, and restoration of cellular volume (YANCEY, 2005). Osmoprotectants commonly used in artificial tears are erythritol, glycerol, L-carnitin, and betaine (BAUDOUIN et al., 2013). L-carnitin and erythritol protect the corneal cells against osmotic stress (CORRALES et al., 2008). Betaine suppresses the expression, production, and activation of metalloproteinases (DENG et al., 2014). Metalloproteinases are enzymes responsible for tissue remodeling. However, in a hyperosmotic environment, their production is increased and can lead to corneal ulcers and corneal melting. Thus, the control of metalloproteinase expression is desirable (PERCHES et al., 2012).

Preservatives are added to the formulations to prevent contamination in the bottle, which may cause severe ocular infections (DOGRU et al., 2013; TU, 2014). However, these substances are highly toxic to the ocular surface when chronically used, and may worsen the inflammation and disease (DEWS, 2007; DOGRU et al., 2013; TU, 2014). While this toxicity is dose-dependent, even the low concentrations reported in commercial products can cause deleterious effects (EPSTEIN et al., 2009). Although less toxic preservatives have been developed, none are completely non-toxic (DEWS, 2007). The main preservatives are detergents (benzalkonium chloride, cetrimide, polyquad) or oxidative agents (sodium perborate, stabilized oxychloro complex) (NOECKER, 2001).

Benzalkonium chloride (BAK) has been the most frequently used preservative in the last few decades and is extremely toxic to the conjunctival and corneal cells (DEWS, 2007; TU, 2014). When chronically used, it destabilizes the lacrimal film, and affects the intercellular junctions, the cellular morphology, and the microvilli. It also reduces the goblet cell density, thus altering the mucin layer, and can eventually cause apoptosis or necrosis and epithelial desquamation (LABBÉ et al., 2006; DEWS, 2007; KAUR et al., 2009). Toxicity is dependent on concentration, frequency of administration, severity of the ocular disease and the level of lacrimal secretion (DEWS, 2007). Therefore, the deleterious effects are worse in KCS patients due to the high exposure of corneal epithelium and the low volume of tears to dilute the drug (NOECKER, 2001). In addition, there is evidence that BAK, which is also found in eyedrops for glaucoma, can penetrate the globe and affect the trabecular meshwork (NOECKER et al., 2001; BAUDOUIN et al., 2012).

A clinical trial comparing ophthalmic solutions containing BAK against preservative-free formulations demonstrated that the preservativefree treatment leads to significant improvement on the Schirmer test, TBUT and impression cytology compared to solutions containing BAK (JEE et al., 2014). Furthermore, the preservative can interfere with the anti-oxidative and anti-inflammatory responses on the ocular surface (JEE et al., 2014). Even though the toxicity of BAK is well established, it is still used in many ophthalmic solutions (Table 1) (LABBÉ et al., 2006).

Polyquaternium-1 (Polyquad) is a quaternary ammonium compound (TU, 2014). 
Although it is a detergent similar to BAK, its toxicity is restricted due to its high molecular weight, which limits epithelial cell penetration, thereby reducing the damage to the lacrimal film and ocular surface (LABBÉ et al., 2006).

Oxidative preservatives, such as sodium perborate and stabilized oxychloro complex, have antibacterial action and minimal toxicity (KAURet al., 2009; NOECKER, 2001). Sodium perborate dissolves in water and releases hydrogen peroxide, which when in contact with the ocular surface is in turn converted into water, chlorine and oxygen (natural tear components) (NOECKER, 2011). However, hydrogen peroxide, even at low concentrations, may injure the ocular surface (KAUR et al., 2009; NOECKER, 2001).

Stabilized oxychlorocomplex, or Prurite $^{\circledR}$, is a mixture of oxychloro species (chlorite $99.5 \%$, chlorate $0.5 \%$ and traces of chlorine dioxide) that have anti-bacterial, anti-fungi and anti-viral action (KAUR et al., 2009; NOECKER, 2001). The mechanism of action is the release of chlorine dioxide in acidic microbial environments, and the interference with microbial protein synthesis (KAUR et al., 2009). When in contact with the lacrimal film, it is converted into natural tear components such as water, oxygen, sodium, and chlorine (NOECKER, 2001). This preservative has mild cytotoxic effects, good tolerance, and an excellent safety record (NOECKER, 2001; KAUR et al., 2009). In a clinical trial, Prurite ${ }^{\circledR}$ had considerably minor deleterious effects (SIMMONS \& VEHIGE, 2007). Nonetheless, it has been shown to cause superficial punctate corneal fluorescein staining (SCHRAGE et al., 2012).

The toxic effects of the preservatives are determined by their concentration, retention time, and frequency of administration (TU, 2014). Therefore, they are considered safe when applied less than six times a day (DEWS, 2007). When frequent instillation is necessary or the tear flow is reduced, a preservative-free solution is recommended (DEWS, 2007).

Preservative-free solutions are mostly packed in single-use vials (DOGRU et al., 2013). There are two main disadvantages to this method of packaging: the higher cost and the difficulty of carrying multiple vials, which leads to a low compliance (GRAHN \& STOKEY, 2004). As an alternative, preservative-free multiple-dose vials are available, with filters that prevent contamination in the bottle (LÓPEZ-GARCÍA \& GARCÍALOZANO, 2012).
Formulation choice

The choice of which eye drop to prescribe must take into account factors such as cost, packaging, availability, clinician preferences, type and severity of the lacrimal abnormality and patient response (GRAHN\&STOREY, 2004; RIBEIRO et al., 2008).

For quantitative abnormalities of the aqueous layer, viscous eyedrops are recommended, where the viscosity is dependent on the severity of the disease. For qualitative abnormalities, ointments or mucinomimetics are recommended (GRAHN \& STOREY, 2004). In addition, due to the high retention time, ointments are recommended for treating severe cases (ZHANG, 2014). In veterinary medicine, the recommended frequency of application is more than 6 times a day. Because this could be unfeasible for pet owners, ointments could be prescribed to reduce the number of applications to 4 times a day. However, lacrimomimetics are not used as a sole therapy in most cases. For example, when used to treat $\mathrm{KCS}$, lacrimomimetics are not effective as a sole therapy and should instead be administered as an adjunct to lacrimostimulants (GRAHN \& STOREY, 2004).

Based on studies on the evaluation of ocular lubricant formulations, MOSHIRFAR et al. (2014) developed an algorithm that guides this choice for human patients: the first choice should be $\mathrm{CMC}$, HPMC or $\mathrm{SH}$ based eye drops. If the improvement is not as expected after instilling the eye drops 4 times a day for 60 days, the eye drops should be exchanged for a HPG or PEG/ Glycerin-based eye drop. If the response is still not as expected or when the condition is severe, or in cases exposure keratopathy or lid malposition, the choice should be to add gels, ointments, or liposome sprays. DOGRU et al. (2013) summarized the decision matrix according to the drop components, severity, and type of disease.

It should be noted that in cases of severe disease, choosing a preservative-free eye drop, regardless of lubricant component, should be the highest priority, and is critical to avoid exacerbating the condition (DEWS, 2007).

\section{CONCLUSION}

An important limitation in the literature is that most studies have been single center comparisons between two or three formulations. The literature lacks a broad, randomized, multicenter study that compares a large variety of solutions. Moreover, 
although there are many studies with experimental animal models, the literature targeting veterinary medicine is limited, and more research focusing on domestic animals is necessary.

\section{REFERENCES}

AMRANE, M. et al. Ocular tolerability and efficacy of a cationic emulsion in patients with mild to moderate dry eye disease - A randomised comparative study. Journal Françaisd'Ophtalmologie, v. 37 n. 8, p.589-598, 2014. Available from: <http://www.ncbi. nlm.nih.gov/pubmed/25127703>. Accessed: Jul. 26, 2015. doi: 10.1016/j.jfo.2014.05.001.

ARAGONA, P. et al. Sodium hyaluronate eye drops of different osmolarity for the treatment of dry eye in Sjögren's syndrome patients. British journal of ophthalmology, v. 86, n. 8, p.879884, 2002. Available from: <http://www.ncbi.nlm.nih.gov/pmc/ articles/PMC1771217/>. Accessed: Aug. 23, 2015. doi: 10.1136/ bjo.86.8.879

BAUDOUIN, C. et al. In vitro and in vivo experimental studies on trabecular meshwork degeneration induced by benzalkonium chloride (an American Ophthalmological Society thesis). Transactions of the American Ophthalmological Society, v. 110, p. 40, 2012.

BAUDOUIN, C. et al. Role of hyperosmolarity in the pathogenesis and management of dry eye disease: proceedings of the OCEAN group meeting. Ocular Surface, v. 11, n. 4, p.246-258, 2013. Available from: <http://dx.doi.org/10.1016/j.jtos.2013.07.003>. Accessed: Jul. 30, 2015. doi: 10.1016/j.jtos.2013.07.003.

CALONGE, M. The treatment of dry eye. Survey of Ophthalmology, v.45, p.S227-S239, 2001.

CHRISTENSEN, M.T. Corneal staining reductions observed after treatment with Systane ${ }^{\circledR}$ lubricant eye drops. Advances in therapy, v.25, n.11, p.1191-1199, 2008. Available from: <http:// www.ncbi.nlm.nih.gov/pubmed/18972076>. Accessed: Jul, 15, 2015. doi: 10.1007/s12325-008-0112-0.

COHEN, S. et al. Evaluation of clinical outcomes in patients with dry eye disease using lubricant eye drops containing polyethylene glycol or carboxymethylcellulose. Clinical ophthalmology (Auckland, NZ), v.8, p.157, 2014. Available from: < http://www. ncbi.nlm.nih.gov/pubmed/24403819>. Accessed: Jul. 28, 2015. doi: $10.2147 /$ OPTH.S53822.

COLLIGRIS, B. et al. An update on dry eye disease molecular treatment: advances in drug pipelines. Expert Opinion on Pharmacotherapy, v.15, n.10, p.1371-1390, 2014. Available from: $<$ http://www.ncbi.nlm.nih.gov/pubmed/24773445>. Accessed: Jul. 17, 2015. doi: 10.1517/14656566.2014.914492.

CORRALES, R.M. et al. Effects of osmoprotectants on hyperosmolar stress in cultured human corneal epithelial cells. Cornea, v.27, n.5, p.574-579, 2008. Available from: $<$ http://www. ncbi.nlm.nih.gov/pubmed/18520508>. Accessed: Aug. 04, 2015. doi: 10.1097/ICO.0b013e318165b19e.

DAVIS, K.; TOWNSEND, W. Tear-film osmolarity in norma cats and cats with conjunctivitis. Veterinary ophthalmology, v.14, n.s1, p.54-59, 2011. Available from: <http://www.ncbi nlm.nih.gov/pubmed/21923824>. Accessed: Sep. 26, 2015. doi: 10.1111/j.1463-5224.2011.00916.x.

DAVITT, W.F. et al. Efficacy in patients with dry eye after treatment with a new lubricant eye drop formulation. Journal of Ocular Pharmacology and Therapeutics, v.26, n.4, p.347353, 2010. Available from: <http://www.ncbi.nlm.nih.gov/ pubmed/20653478>. Accessed: Jul. 15, 2015. doi: 10.1089/ jop. 2010.0025

DENG, R.et al. Osmoprotectants suppress the production and activity of matrix metalloproteinases induced by hyperosmolarity in primary human corneal epithelial cells. MolecularVision, v.20, p.1243, 2014.

DEWS (INTERNATIONAL DRY EYE WORKSHOP). Management and therapy of dry eye disease: report of the Management and Therapy subcommittee of the International Dry Eye WorkShop (2007). Ocular Surface, v.5, n.2, p.163-178, 2007. doi: 10.1016/S1542-0124(12)70085-X.

DOGRU, M. et al. Changing trends in the treatment of dry-eye disease. Expert opinion on investigational drugs, v.22, n.12, p.1581-1601, 2013. Available from: <http://www.ncbi.nlm. nih.gov/pubmed/24088227>. Accessed: Aug. 30, 2015. doi: $10.1517 / 13543784.2013 .838557$.

DU TOIT, L.C. et al. Ocular drug delivery-a look towards nanobioadhesives. Expert Opinion on Drug Delivery, v.8, n.1, p.71-94, 2011. Available from: <http://www.ncbi.nlm. nih.gov/pubmed/21174606>. Accessed: Aug. 02, 2015. doi: 10.1517/17425247.2011.542142.

EPSTEIN, S.P. et al. Comparative toxicity of preservatives on immortalized corneal and conjunctival epithelial cells. Journal of ocular pharmacology and therapeutics, v.25, n.2, p.113119, 2009. Available from: <http://www.ncbi.nlm.nih.gov/ pubmed/19284328>. Accessed: Aug. 15, 2015. doi: 10.1089/ jop. 2008.0098

GARRETT, Q. et al. Carboxymethyl cellulose binds to human corneal epithelial cells and is a modulator of corneal epithelial wound healing. Investigative Ophthalmology and Visual Science, v.48, n.4, p.1559, 2007.

GARRETT, Q. et al. Carboxymethyl cellulose stimulates rabbit corneal epithelial wound healing. Current Eye Research, v.33, n.7, p.567-573, 2008. Available from: <http://www.ncbi.nlm. nih.gov/pubmed/18600489>. Accessed: Aug. 05, 2015. doi: $10.1080 / 02713680802140213$

GILBARD, J.P. et al. Ophthalmic solutions, the ocular surface, and a unique therapeutic artificial tear formulation. American Journal of Ophthalmology, v.107,n.4, p.348-355, 1989.

GOMES, J.A.P. et al. Sodium hyaluronate (hyaluronic acid) promotes migration of human corneal epithelial cells in vitro. British journal of ophthalmology, v.88, n.6, p.821-825, 2004

GRAHN, B.H.; STOREY, E.S. Lacrimostimulants and lacrimomimetics. Veterinary Clinics of North America: Small Animal Practice, v.34, n.3, p.739-753, 2004.

HOPKINS, G. Artificial tears and ocular lubricants. In: HOPKINS G.; PEARSON, R. Ophthalmic drugs. 5.ed. Edinburg: ButterworthHeinemann, 2007. p.243-256. 
JEE, D. et al. Antioxidant and inflammatory cytokine in tears of patients with dry eye syndrome treated with preservative-free versus preserved eye drops. Investigative Ophthalmology \& Visual Science, v.55, n.8, p.5081-5089, 2014. Available from: $<$ http://iovs.arvojournals.org/article.aspx?articleid=2128994>. Accessed: Jul. 15, 2015. doi: 10.1167/iovs.14-14483.

KAUR, I.P.et al. Ocular preservatives: associated risks and newer options. Cutaneous and Ocular Toxicology, v.28, n.3, p.93-103, 2009. Available from: <http://www.ncbi.nlm. nih.gov/pubmed/19505226>. Accessed: Aug. 04, 2015. doi: $10.1080 / 15569520902995834$.

KHANAL, S. et al. Effect of an oil-in-water emulsion on the tear physiology of patients with mild to moderate dry eye. Cornea, v.26, n.2, p.175-181, 2007.

LABBÉ, A. et al. Comparison of toxicological profiles of benzalkonium chloride and polyquaternium-1: an experimental study. Journal of Ocular Pharmacology \& Therapeutics, v.22, n.4, p.267-278, 2006.

LÓPEZ-GARCÍA, J.S.; GARCÍA-LOZANO, I. Use of containers with sterilizing filter in autologous serum eyedrops. Ophthalmology, v.119, n.11, p.2225-2230, 2012. Available from: <http://www.aaojournal.org/article/S0161-6420(12)005593/abstract>. Accessed: Jul. 15, 2015. doi: 10.1016/j. ophtha.2012.06.028.

MAGGS, D.J. Update on pathogenesis, diagnosis, and treatment of feline herpesvirus type 1. Clinical Techniques in Small Animal Practice, v.20, n.2, p.94-101, 2005.

MAGGS, D.J. et al. Slatter's fundamentals of veterinary ophthalmology. 4 ed. Saint Louis Elsevier Saunders, 2008. 478 p.

MOORE, C.P. Diseases and surgery of the lacrimal secretory system. In: GELATT, K.N. Veterinary ophtalmology. 3.ed. Philadelphia: Williams \& Wilkins, 1999. p.583-608.

MOORE, P.A. Feline corneal disease. Clinical Techniques in Small Animal Practice, v.20, n.2, p.83-93, 2005.

MOORE, J.E. et al. Effect of tear hyperosmolarity and signs of clinical ocular surface pathology upon conjunctival goblet cell function in the human ocular surface. Investigative Ophthalmology \&Visual Science, v.52, n.9, p.6174-6180, 2011. Available from: <http://iovs.arvojournals.org/article. aspx?articleid=2187187>. Accessed: Aug. 05, 2015. doi: $10.1167 /$ iovs. $10-7022$.

MOSHIRFAR, M.et al. Artificial tears potpourri: a literature review. Clinical ophthalmology (Auckland, NZ), v.8, p.1419, 2014. Available from: <http://www.ncbi.nlm.nih.gov/pmc/ articles/PMC4124072/>. Accessed: Oct. 19, 2015. doi: 10.2147/ OPTH.S65263.

NICHOLS, K.K. et al. The international workshop on meibomian gland dysfunction: executive summary. Investigative ophthalmology \& visual science, v.52, n.4, p.1922, 2011.Available from: <http://www.ncbi.nlm.nih.gov/pmc/articles/PMC3072157/>. Accessed: Jul. 11, 2015. doi: 10.1167/iovs.10-6997a.

NOECKER, R. Effects of common ophthalmic preservatives on ocular health. Advances in therapy, v.18, n.5, p.205-215, 2001.
OUSLER, G.W. et al. An evaluation of tear film breakup time extension and ocular protection index scores among three marketed lubricant eye drops. Cornea, v.26, n.8, p.949-952, 2007.

OUSLER, G.W.et al. An evaluation of Retaine ${ }^{\mathrm{TM}}$ ophthalmic emulsion in the management of tear film stability and ocular surface staining in patients diagnosed with dry eye. Clinical Ophthalmology (Auckland, NZ), v.9, p.235, 2015.

PAPA, V. et al. Comparison of hypotonic and isotonic solutions containing sodium hyaluronate on the symptomatic treatment of dry eye patients. Ophthalmologica, v.215, n.2, p.124-127, 2001.

PERCHES, C.S. et al. Matriz metaloproteinases na reparação corneal. Revisão de literatura. Veterinária e Zootecnia, v.19, n.4, p.480-489, 2012.

REGNIER, A. Clinical Pharmacology and therapeutics. Part 1: Drug delivery and pharmacokinetics. In: GELATT, K.N. et al. Veterinary ophthalmology. Iowa: Wiley-Blackwell, 2013. Chapt.4, p.351-380.

RIBEIRO, A.P. et al. Qualitative and quantitative tear film abnormalities in dogs. Ciência Rural, v.38, n.2, p.568-575, 2008.

SEBBAG, L. et al. Tear film osmolarity measurements using the TearLab TM osmometer in normal dogs and dogs with dry eye disease. Investigative Ophthalmology \& Visual Science, v.55, n.13, p.1967-1967, 2014.

SCHMIDT, T.A. et al. Transcription, translation, and function of lubricin, a boundary lubricant, at the ocular surface. Journal American Medical, Association ophthalmology, v.131, n.6, p.766-776, 2013. Available from: <http://www.ncbi.nlm.nih. gov/pubmed/23599181>. Accessed: Jul. 17, 2015. doi: 10.1001/ jamaophthalmol.2013.2385.

SCHRAGE, N. et al. The ex vivo eye irritation test (EVEIT) in evaluation of artificial tears: Prurite ${ }^{\circledR}$-preserved versus unpreserved eye drops. Graefe's Archive for Clinical and Experimental Ophthalmology, v.250, n.9, p.1333-1340, 2012. Available from: <http://link.springer.com/article/10.1007\%2 Fs00417-012-1999-3>. Accessed: Aug. 04, 2015. doi: 10.1007/ s00417-012-1999-3.

SIMMONS, P.A.; VEHIGE, J.G. Clinical performance of a midviscosity artificial tear for dry eye treatment. Cornea, v.26, n.3, p.294-302, 2007.

SIMMONS, P.A. et al. Efficacy, safety, and acceptability of a lipid-based artificial tear formulation: a randomized, controlled, multicenter clinical trial. Clinical therapeutics, v.37, n.4, p.858868, 2015a. doi: 10.1016/j.clinthera.2015.01.001.

SIMMONS, P.A. et al. Efficacy and safety of two new formulations of artificial tears in subjects with dry eye disease: a 3-month, multicenter, active-controlled, randomized trial. Clinical Ophthalmology (Auckland, NZ), v.9, p.665, 2015b. Available from: <http://www.ncbi.nlm.nih.gov/pmc/articles/PMC4404880/>. Accessed: Jul. 15, 2015. doi: 10.2147/OPTH.S78184.

SPRINGS, C. Novel ocular lubricant containing an intelligent delivery system: details of its mechanism of action. In: BREWITT, H. Research projects in dry eye syndrome. Basel: Karger, 2010. V.45, p.129-147. doi: 10.1159/000315027. 
TOMLINSON, A. et al. Tear film osmolarity: determination of a referent for dry eye diagnosis. Investigative Ophthalmology \& Visual Science, v.47, n.10, p.4309-4315, 2006.

TROIANO, P.; MONACO, G. Effect of hypotonic $0.4 \%$ hyaluronic acid drops in dry eye patients: a cross-over study. Cornea, v.27, n.10, p.1126-1130, 2008. Available from: <http://www.ncbi. nlm.nih.gov/pubmed/19034126>. Accessed: Sep. 12, 2015. doi: $10.1097 / \mathrm{ICO} .0 \mathrm{~b} 013 \mathrm{e} 318180 \mathrm{e} 55 \mathrm{c}$

TSUBOTA, K. et al. New treatment of dry eye: the effect of calcium ointment through eyelid skin delivery. British Journal of Ophthalmology, v.83, n.7, p.767-770, 1999.

TU, E.Y. Balancing antimicrobial efficacy and toxicity of currently available topical ophthalmic preservatives. Saudi Journal of Ophthalmology, v.28, n.3, p.182-187, 2014 Available from: <http:/www.sciencedirect.com/science/article/ pii/S1319453414000721>. Accessed: Jul. 09, 2015. doi: 10.1016/j. sjopt.2014.06.006

UBELS, J.L.et al. Effects of preservative-free artificial tear solutions on corneal epithelial structure and function. Archives of ophthalmology, v.113, n.3, p.371-378, 1995
UBELS, J.L.et al. Pre-clinical investigation of the efficacy of an artificial tear solution containing hydroxypropyl-guar as a gelling agent. Current eye research, v.28, n.6, p.437-444, 2004.

VICARIO-DE-LA-TORRE, M.et al. Design and characterization of an ocular topical liposomal preparation to replenish the lipids of the tear. Investigative Ophthalmology \& Visual Science, v.55, n.12, p.7839-7847, 2014. Available from: $<$ http://iovs.arvojournals. org/article.aspx? articleid=2212639> . Accessed: Jul. 24, 2015. doi: $10.1167 /$ iovs.14-14700.

WILLIAMS, D.L. Immunopathogenesis of keratoconjunctivitis sicca in the dog. Veterinary Clinics of North America: Small Animal Practice, v.38, n.2, p.251-268, 2008.

YANCEY, P.H. Organic osmolytes as compatible, metabolic and counteracting cytoprotectants in high osmolarity and other stresses. Journal of Experimental Biology, v.208, n.15, p.2819-2830, 2005.

ZHANG, W. et al. A novel nanoscale-dispersed eye ointment for the treatment of dry eye disease. Nanotechnology, v.25, n.12, p.125-101, 2014. Available from: <http://www.ncbi.nlm.nih.gov/ pubmed/24571862>. Accessed: Jul. 16, 2015. doi: 10.1088/0957$4484 / 25 / 12 / 125101$ 


\section{ERRATUM}

Artigo "Ocular lubricants: what is the best choice?" publicado em Ahead Of Print em 1 de agosto de 2016 da Ciência Rural, onde se lia:

\section{"Daniela Lins de Macedo"}

leia-se:

\section{"Daniela Macedo Lins de Araújo"}

Para a versão correta, acesse:

http://www.scielo.br/pdf/cr/2016nahead/1678-4596-cr-0103_8478cr20160020.pdf 